\title{
Matrix metalloproteinase-2, squamous cell carcinoma antigen, and tissue polypeptide-specific antigen expression in Egyptian patients with cervical carcinoma: Relationship with prognosis
}

\author{
Maha Imam Ahmed ${ }^{\mathrm{a}}$, Eman-El Salahy ${ }^{\mathrm{a}}$, Hassan Tawfiq ${ }^{\mathrm{b}}$, Ali Khalifa ${ }^{\mathrm{a}}$ and Manal M. Hassan ${ }^{\mathrm{c}, *}$ \\ ${ }^{a}$ Biochemistry Department, Ain Shams Faculty of Medicine, Cairo, Egypt \\ ${ }^{\mathrm{b}}$ Obstetrics and Gynecology Department, Ain Shams Faculty of Medicine, Abbassia, Cairo, Egypt \\ ${ }^{\mathrm{c}}$ Department of Gastrointestinal Medical Oncology, The University of Texas M. D. Anderson Cancer Center, \\ Houston, TX, USA
}

\begin{abstract}
Matrix metalloproteinases (MMPs), a family of proteolytic enzymes produced by both stromal and tumor cells, appear to have a key role in the events leading to local invasion and metastasis by malignant neoplasms. In the present study, we evaluated the role of MMP-2, squamous cell carcinoma antigen (SCCA), and tissue polypeptide - specific antigen (TPS) in cervical neoplasia.

Using Western blotting and enzyme immunoassay (EIA), we analyzed 50 patients with cervical carcinoma (CC) and 25 normal controls for expression of MMP-2 in tissue cell lysates. We also quantified SCCA and TPS with microparticle immunoassay and EIA, respectively. The results were correlated with human papilloma virus (HPV) infection, clinicopathological findings, and disease outcome. The cutoff point for each marker was estimated from receiver operating characteristic curves. Logistic regression analysis was performed to estimate the odds ratio (OR) and 95\% confidence interval (CI) for each marker.

MMP-2, SCCA, and TPS protein expression were significantly higher in patients with CC than in normal controls. While TPS was the best marker for discriminating between patients and controls, MMP-2 was associated with an advanced tumor stage (OR, 13.9 [95\% CI, 1.4-133.9]) and poor histological grade (OR, 10.2 [95\% CI, 1.7-60.5]). Moreover, independent of the effect of an advanced CC stage and grade, the patients' age, and the presence of HPV infection, MMP-2 was considered a strong predictor for $\mathrm{CC}$ recurrence (OR, 8.1 [95\% CI, 1.3- 49.1]).

Tissue markers may be used to select high-risk patients for early detection of and adjuvant therapy for recurrence. Our MMP-2 findings are particularly relevant to the development of protease inhibitors as a new cancer therapy approach.
\end{abstract}

Keywords: Cervical carcinoma, metalloproteinases, polypeptide - specific antigen, cervical neoplasms, recurrence

\section{Introduction}

The extent of disease at initial diagnosis is one of the most crucial factors in determining treatment strategies

* Address for reprints, Manal M. Hassan, M.D., Ph.D., Department of Gastrointestinal Medical, Unit 426, The University of Texas M.D. Anderson Cancer Center, 1515 Holcombe Boulevard, Houston, TX 77030, USA. Tel.: +1 713792 2828; Fax: +1 713745 1163; E-mail: mhassan@mdanderson.org. for cervical carcinoma (CC) [1]. Dissemination of malignant neoplasms is a multistep process that involves degradation of subepithelial basement membranes and the extracellular matrix (ECM) [2]. Members of the matrix metalloproteinase (MMP) family of zinc- and calcium-dependent enzymes appear to play a key role in tumor invasion and metastasis, as they are able to degrade most ECM components [3-7]. There are at least 24 known MMPs, which are classified according to their substrate specificity as interstitial collagenases, 
stromelysins, gelatinases, elastases, and membranetype MMPs [8,9].

One MMP in particular, MMP-2 (a 72-kDa type IV collagenase/gelatinase A), is able to degrade type IV collagen and fibronectin components of all basement membranes, thereby facilitating stromal and vascular invasion by tumor cells $[4,8]$. The degradative action of MMP-2 is modified by tissue inhibitor of MMP-2 (TIMP-2), which is a $22-\mathrm{kDa}$ protein that forms a $1: 1$ stoichiometric complex with the active site of the enzyme $[10,11]$. Activation of pro-MMP-2 requires the formation of a ternary complex, which is initiated via binding of TIMP-2 to the TIMP-2 membrane receptor (MTI-MMP). The MTI-MMP-TIMP-2 complex then binds to the carboxyl-end domain of pro-MMP-2, resulting in enzyme activation [12]. Expression of MMP2 immunoreactive protein is an early change in the cascade of events that lead to malignant transformation in cervical neoplasia [13] and was found to correlate with the metastatic phenotype and/or survival in uterine CC [14].

Tumor markers have been shown to be useful in the prediction of prognosis, evaluation of response to therapy, and early detection of recurrence in cases of human malignancy. Specifically, in 1977, Kato and Torigoe [15] were the first to describe squamous cell carcinoma (SCC) antigen (SCCA). A subfraction of TA-4, SCCA is a tumor antigen that is found in SCC tissue of the uterine cervix. This antigen has a molecular weight of $48,000 \mathrm{kDa}$ and is almost a pure protein, having a carbohydrate content of $<0.6 \%$ [16]. In addition, recent molecular studies showed that SCCA is transcribed by two almost identical tandemly arrayed genes, SCCA1 and SCCA2, which are members of the high-molecularweight serine proteinase inhibitor (serpin) superfamily. Although SCCA1 and SCCA2 are 90\% identical at the amino acid level, they have distinct biochemical properties. Paradoxically, SCCA1 is an inhibitor of papainlike cysteine proteinases, such as cathepsin L, S, and $\mathrm{K}$, whereas SCCA2 inhibits chymotrypsin-like serine proteinases, cathepsin G, and mast cell chymase [17]; furthermore, expression of SCCA2 has been found to be elevated in sera and tissue extracts obtained from patients with CC $[16,18]$.

In addition, tissue polypeptide-specific antigen (TPS) is a cytokeratin marker related to the tumor marker tissue polypeptide antigen (TPA). It is recognized by a monoclonal antibody against the M3 epitope of TPA [19] and is specific for squamous and glandular epithelium and malignant epithelial tissues. It is thought that the TPS concentration provides informa- tion about tumor activity on a biochemical level long before the clinical manifestations of the cancer are noticed. The TPS level indicates the proliferative activity of malignant tissue even if the tumor is small [20]. TPS has been proposed as a useful marker in the evaluation of treatment response and early detection of relapse in a variety of human malignancies, such as pancreatic, prostate, gastrointestinal, and cervical tumors [21-24].

In Egypt, $\mathrm{CC}$ is the most common female genital tract malignancy, but it has an undefined complete epidemiological picture in terms of its contributing risk factors and peculiar younger age at onset. With the above in mind, we sought to examine the expression of MMP-2, SCCA, and TPS in Egyptian women with CC. Furthermore, we sought to determine the correlation between Markers level and clinicopathological features and patient outcome.

\section{Methods}

\subsection{Study population}

The study population consisted of patients with $\mathrm{CC}$ who received treatment in the Obstetrics and Gynecology Department at Ain Shams University Hospitals in Cairo, Egypt from October 1998 through December 2001. Specifically, CC tissue specimens were collected from patients having the disease at different stages; cervical tissue specimens obtained from patients who underwent a hysterectomy for a nonmalignant condition were used as controls. All patients were prospectively enrolled in the study and had provided verbal and written consent to donate their tissue specimens for this investigation, as required by Ain Shams University Hospital.

Patients with CC were examined while under general anesthesia to assess tumor size and parametrial and/or vaginal extension of the tumor. Per-rectal examination and cystoscopy were also performed along with biopsy analysis when indicated. The clinical stage of $\mathrm{CC}$ was determined according to the International Federation of Gynecology and Obstetrics (IFGO) staging system. According to the clinical stage of their disease, patients underwent a radical hysterectomy, radiotherapy, or both. Patients with a bulky tumor ( $>$ $4 \mathrm{~cm}$ in diameter) received neoadjuvant chemotherapy before undergoing definitive hysterectomy and/or radiotherapy. Surgically resected tissue specimens were obtained before therapy and stored at $-80^{\circ} \mathrm{C}$ until they were used for detection of MMP-2 via enzyme im- 
munoassay (EIA) and Western blotting and quantification of SCCA and TPS via microparticle immunoassay (MEIA) and EIA, respectively. Representative hematoxylin- and eosin-stained sections of each frozen tissue block were examined microscopically to confirm the presence of tumor cells; only patients with a confirmed pathological diagnosis were included in the study. A total of 50 patients with $\mathrm{CC}$ and 25 controls participated in this study. Evidence of infection with human papilloma virus (HPV) was confirmed in all patients and controls.

\subsection{Laboratory methods}

\subsubsection{Preparation of cell lysates}

Tissue specimens $(1 \%[\mathrm{w} / \mathrm{v}])$ were homogenized and lysed on ice with the Power Gene 700 homogenizer (Fisher Scientific International, Hampton, $\mathrm{NH})$ in cold extraction buffer $(10 \mathrm{mmol} / \mathrm{L}$ HEPES buffer, $\mathrm{pH} 7.5$, containing $10 \mathrm{mmol} / \mathrm{L} \quad \mathrm{K}_{2}$ EDTA, $50 \mathrm{mmol} / \mathrm{L} \mathrm{NaCl}, 5 \mathrm{mmol} / \mathrm{L}$ benzamidine, $10 \mathrm{mmol} / \mathrm{L}$ 2-mercaptoethanol, $0.39 \mathrm{mmol} / \mathrm{L}$ phenylmethylsulfonyl flouride, and $5 \mathrm{mg} / \mathrm{L}$ aprotinin, $\mathrm{pH}$ 7.5) and processed as described previously [25]. After centrifugation at 20,000 $\mathrm{g}$ for $20 \mathrm{~min}$ at $4{ }^{\circ} \mathrm{C}$ with a Beckman L7 ultracentrifuge (Beckman Coulter, Inc., Fullerton, CA), the supernatant (cell lysate) was frozen at $-80^{\circ} \mathrm{C}$. The protein concentrations in the cell lysates were quantified by using a Bradford assay kit (Bio-Rad, Hercules, CA ) with bovine serum albumin as the calibrator [26].

\subsubsection{Measurement of MMP-2 in cell lysates with EIA}

MMP-2 was quantified in cell lysates with the human MMP-2 EIA system (Oncogene Research Products, San Diego, CA). The results were expressed as $\mathrm{ng} / \mathrm{mg}$ total tissue proteins.

\subsubsection{Detection of MMP-2 protein in cell lysates with Western blotting}

Western blots were performed by using the method described by Eissa and Seada [25]. Cell lysates were diluted in a sodium dodecyl sulfate-polyacrylamide gel electrophoresis sample buffer in the presence of mercaptoethanol and boiled for $5 \mathrm{~min}$. Samples $(100 \mu \mathrm{g}$ of protein/lane) were separated with the use of $10 \%$ polyacrylamide gel electrophoresis, and bands were transferred to nitrocellulose paper (Bio-Rad) in a tris-glycine transfer buffer (25 mM Tris, $192 \mathrm{mM}$ glycine, $20 \%$ methanol, $\mathrm{pH} 7.4$ ) for $5 \mathrm{~h}$ at $60 \mathrm{~V}$. Next, nitrocellulose filters were washed, and unoccupied binding sites were blocked with $5 \%$ bovine serum albumin in TBS buffer
(50 mM Tris, pH 7.4, $150 \mathrm{mM} \mathrm{NaCl,} 2$ mM EDTA, $0.1 \% \mathrm{NP} 40$ ) for $1 \mathrm{~h}$ at room temperature and then incubated overnight with a MMP-2 monoclonal antibody (ab-6; Oncogene Research Products) diluted at a ratio of $1: 600$, at $4^{\circ} \mathrm{C}$. The membranes were washed with phosphate-buffered saline containing $0.3 \%$ Tween and visualized by using alkaline phosphatase-conjugated goat anti-mouse IgG (Oncogene Research Products) diluted at a ratio of 1:2000 for $90 \mathrm{~min}$ at room temperature. Proenzyme MMP-2 (Oncogene Research Products) was used as a positive control.

\subsubsection{Quantification of SCCA using MEIA}

SCCA was measured in cell lysates as a subfraction of TA-4 with the Imx-SCCA assay, which is based on MEIA technology (Abbott Laboratories, Abbott Park, IL). SCCA bound to anti-SCCA-coated microparticles in the specimen, forming an antibody-antigen complex, which was transferred to the glass fiber matrix. The anti-SCCA alkaline phosphatase conjugate (secondary antibody) was dispensed onto the matrix and bound to the antibody-antigen complex. The substrate (4methylumbelliferyl phosphate) was then added, and the rate of fluorescent product formation was measured with the MEIA optical assembly. The SCCA level was expressed as $\mathrm{ng} / \mathrm{mg}$ tissue protein.

\subsubsection{TPS assay using TPS EIA}

TPS was measured with an EIA kit (TPS enzymelinked immunoassay): Beki Diagnostic AB, Bromma, Sweden), which quantifies the M3-epitopes of the soluble fragments of cytokeratin 18 in the cell lysate. Patient cell lysates containing cytokeratin 18 fragments were simultaneously reacted in a polystyrene microplate (well) coated with polyclonal horse antibodies directed against cytokeratin proteins and a horseradish peroxidase-conjugated anti-M3 monoclonal antibody; 3,3',5,5'-tetramethylbenzidine was used as a substrate. The absorbance was measured using a microplate reader at $450 \mathrm{~nm}$, and the amount of TPS in each sample was calculated using a standard curve plotted on a log-log scale. The TPS level was expressed as ng/mg protein.

\subsubsection{Polymerase Chain Reaction (PCR) for HPV-16}

In a $100-\mu 1$ total reaction volume, crude DNA extract (about $1000 \mathrm{ng}$ ) was incubated in a reaction mixture containing $10 \mathrm{mM}$ Tris-HCL ( $\mathrm{pH} 8.3$ ), $1.5 \mathrm{mM}$ $\mathrm{Mg}$ chloride, $0.2 \mathrm{mM}$ deoxynucleotide triphosphate, 50 pmol of oligonucleotide primers, and $0.25 \mathrm{U}$ of thermostable Taq polymerase (Promega, Madison, WI). 
The oligonucleotide primers used for HPV were 320339 5' ATT AGT GAG TAT AGA CAT TA 3', and 410-4295 GGC TTT TGA CAG TTA ATA CA 3'. The amplification reaction was carried out in a thermocycler (Hybaid Omnigene thermal cycler Thermo Electron Corporation, UK) under the following conditions: 30 cycles at $94^{\circ} \mathrm{C}$ for $1 \mathrm{~min}, 46^{\circ} \mathrm{C}$ for $3 \mathrm{~min}$, and $72^{\circ} \mathrm{C}$ for $3 \mathrm{~min}$. The PCR products as well as a DNA molecular weight marker (Promega) were electrophoresed on $2 \%$ agarose gels containing ethidium bromide $(80 \mathrm{ng} / \mathrm{ml})$. The gels were examined under ultraviolet illumination. A cultured cell line known to contain HPV-16 HK-2 transduced with HPV-16 genes; American Type Culture Collection, Rockville, MD, was used as a positive control.

\subsection{Statistical methods}

Data analysis was performed using five different subgroups: 1) cancer status (CC patients versus controls), 2) relapse status (relapsed versus nonrelapsed CC), 3) histological grade (grades I-II versus grade III), 4) cancer stage (stages I-II versus stages III-IV), and 5) pathological classification SCC versus adenocarcinoma $[\mathrm{AC}]$.

The median biochemical values were given for patients and controls. Also, the nonparametric MannWhitney test was performed to calculate the mean rank of measured parameters within both groups.

Receiver operating characteristic (ROC) curves [27] were drawn for all three study markers by plotting the true-positive rate (sensitivity) against the false-positive rate (1-specificity). A test that perfectly discriminates between variables with no overlap of results from categories in each of the above subgroups has a ROC curve that passes through the top left corner, where the maximum specificity and sensitivity values are located. The area under the curve (AUC) and its $95 \%$ confidence interval (CI) were calculated as a single measurement of the diagnostic efficacy of the continuous test results. If a test does not have any diagnostic value, the AUC will be close to 0.5 ; if it has a strong diagnostic value, the AUC will be close to 1.0. For markers with a significant AUC, the positive likelihood ratio (LR+) was estimated based on the ratio between the true- and false-positive rates (sensitivity/1-specificity) of several cutoff values. The LR + is similar to the relative risk in epidemiology: the greater the $\mathrm{LR}+$, the greater the diagnostic value of a positive test result. The cutoff value with the highest $\mathrm{LR}+$ was used to discriminate between the categories of the subgroups described above [28].
To estimate the magnitude of an association between MMP-2, SCCA, and TPS and the likelihood of developing CC, poor histological grade, advanced tumor stage, SCC, and tumor relapse, multivariate analysis with different logistic regression models was applied. Adjusted odds ratios (ORs) and 95\% CIs were estimated using the logistic regression coefficients. The SPSS software program (version 11; SPSS Inc., Chicago, IL) was used for the analysis.

The population attributable risk percentage (PAR\%) for HPV infection was calculated using the OR of the infection and its prevalence $\left(\mathrm{P}_{\mathrm{HPV}}\right)$ in the control group: $\mathrm{PAR} \%=\left[\mathrm{P}_{\mathrm{HPV}}(\mathrm{OR}-1) / \mathrm{P}_{\mathrm{HPV}}(\mathrm{OR}-1)+1\right] \times 100$.

\section{Results}

\subsection{Patient characteristics}

This study included 75 subjects: 50 patients with CC (mean age \pm standard deviation [SD], $51.8 \pm 7.2$ years) and 25 controls (mean age $\pm \mathrm{SD}, 47.8 \pm 9.0$ years). Of the CC patients, 31 (62\%) had SCC, and 19 (38\%) had $\mathrm{AC}$. The CC cases were clinically staged according to the IFGO staging system, with the cases distributed by stage as follows: 12 at stage I, 12 at stage II, 14 at stage III, and 12 at stage IV. Additionally, CC cases were classified histologically as grade I/II (34 cases [68\%]) or III/IV (16 cases [32\%]). Nineteen patients experienced local recurrence $(n=7)$ or distant metastasis ( $n=12$ ) during the follow-up period (median duration, 21 months [range, 6-36 months]).

\subsection{Study markers and the risk of $\mathrm{CC}$}

The mean ranks of the different parameters measured were significantly higher in malignant cervical tissue specimens than in normal cervical tissue specimens obtained from controls (Table 1).

As a single marker, TPS (AUC, 0.859) was significantly better than SCCA (AUC, 0.701) and MMP-2 (AUC, 0.797) at discriminating between carcinoma and benign disease. The optimal cutoff values for MMP-2, SCCA, and TPS are shown in Fig. 1. Age and infection with HPV are significant risk factors for CC. The estimated univariate OR for age was 1.1 (95\% CI, 1.01.14). Also, the proportion of subjects infected with HPV was significantly higher in the patients $(n=34$ [68\%]) than in the controls ( $n=7$ [28\%]) yielding a significant OR for the association between HPV and CC (OR, 5.5 [95\% CI, 1.9-15.7]). Both AC and SCC 
Table 1

MMP-2, SCCA, and TPS levels in patients with CC and controls as analyzed using the Mann-Whitney test

\begin{tabular}{lccc}
\hline & Patients & Controls & $P$ \\
\hline $\begin{array}{l}\text { MMP-2 } \\
\text { Median (range) }\end{array}$ & $15.2(5.5-39.5)$ & $8.5(4.9-15.7)$ & 0.0001 \\
$\begin{array}{l}\text { SCCA } \\
\text { Median (range) }\end{array}$ & $1.2(0.1-4.00)$ & $0.5(0.1-3.4)$ & 0.0001 \\
$\begin{array}{l}\text { TPS } \\
\text { Median (range) }\end{array}$ & $657.3(455.5-880.0)$ & $450.5(364.5-584.6)$ & 0.0001 \\
\hline
\end{tabular}

${ }^{\text {a }}$ Variable expressed in $\mathrm{ng} / \mathrm{mg}$ protein.

${ }^{\mathrm{b}}$ Variable expressed in $\mu \mathrm{g} / \mathrm{mg}$ protein.

Table 2

Association between MMP-2, SCCA, and TPS and development of $\mathrm{CC}$ using multiple logistic regression analysis

\begin{tabular}{|c|c|c|c|}
\hline Tumor marker & $\begin{array}{c}\text { Patients } \\
\mathrm{N}(\%)\end{array}$ & $\begin{array}{c}\text { Controls } \\
\mathrm{N}(\%)\end{array}$ & $\begin{array}{c}\text { Adjusted OR } \\
(95 \% \mathrm{CI})^{\mathrm{a}}\end{array}$ \\
\hline \multicolumn{4}{|c|}{ MMP-2 (ng/mg protein) } \\
\hline$<10.3$ & $11(22)$ & $18(72)$ & 1 \\
\hline$\geqslant 10.3$ & $39(78)$ & $7(28)$ & $4.7(1.1-21.5)$ \\
\hline \multicolumn{4}{|c|}{$\operatorname{SCCA}(\mu \mathrm{g} / \mathrm{mg}$ protein $)$} \\
\hline$<1.02$ & $17(34)$ & $18(72)$ & 1 \\
\hline$\geqslant 1.02$ & $33(66)$ & $7(28)$ & $6.3(1.8-21.4)$ \\
\hline \multicolumn{4}{|c|}{ TPS (ng/mg protein) } \\
\hline$<524$ & $14(28)$ & $22(88)$ & 1 \\
\hline$\geqslant 524$ & $36(72)$ & $3(12)$ & $23.9(4.9-115.2)$ \\
\hline
\end{tabular}

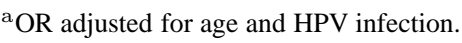

are significantly associated with HPV infection. The estimated age-adjusted OR was $5.5(0.95 \%$ CI, $1.5-$ 20.3) and 5.9 (95\% CI, 1.7-20.3) for AC and SCC, respectively.

The estimated PAR\% for HPV infection was 56\%, implying that approximately half of the cases of CC in this study are attributable to HPV infection. Therefore, both the patients' age and HPV infection were considered to be covariates in the multivariate analysis.

Expression of all of the markers was significantly related to the development of CC; the estimated HPV- and age-adjusted ORs and 95\% CIs are shown in Table 2. For example, people with MMP-2 expression at a value $\geqslant 10.3 \mathrm{ng} / \mathrm{mg}$ protein had an approximately five times greater risk of $\mathrm{CC}$ development than did those with a value $<10.3 \mathrm{ng} / \mathrm{mg}$ protein after adjustment for the confounding effect of patients' age and HPV infection.

\subsection{Correlation of study markers with tumor characteristics}

The association between each of the study tumor markers (MMP-2, TPS, and SCCA) and clinical characteristics of $\mathrm{CC}$ are presented in Fig. 2. MMP-2 was the most significant marker in discriminating between early and advanced tumor stages and good and poor his- tological grades. The AUC of MMP-2, was 0.837 (95\% CI, 0.727-0.946) and 0.721 (95\% CI, 0.552-0.890), for stage and grade respectively.

The estimated age-and HPV-adjusted OR and 95\% $\mathrm{CI}$ at each selected cutoff point of MMP-2 according to histological grade (Model 1) and IFGO stage (Model 2) are shown in Table 3. For example, patients with $\mathrm{CC}$ who had an MMP-2 value $\geqslant 16.9 \mathrm{ng} / \mathrm{mg}$ protein were 10 times more likely to have a tumor with a poor histological grade (grade III) than a tumor with a lesser grade, with the consideration of adjustment for the confounding effect of age and HPV infection.

None of the markers were related to the pathological subtype (SCC or AC). The median values for MMP2, TPS, and SCCA was $15.5 \mathrm{ng} / \mathrm{mg}$ protein (range, 7.3$37.9 \mathrm{ng} / \mathrm{mg}$ protein), $660 \mathrm{ng} / \mathrm{mg}$ protein (range, $473.5-$ $880 \mathrm{ng} / \mathrm{mg}$ protein), and $1.2 \mu \mathrm{g} / \mathrm{mg}$ protein (range, $0.1-$ $2.3 \mu \mathrm{g} / \mathrm{mg}$ protein), respectively, in patients with $\mathrm{AC}$ and $13.6 \mathrm{ng} / \mathrm{mg}$ protein (range, $5.5-39.5 \mathrm{ng} / \mathrm{mg}$ protein), $654.5 \mathrm{ng} / \mathrm{mg}$ protein (range, $455-877.8 \mathrm{ng} / \mathrm{mg}$ protein), and $1.1 \mu \mathrm{g} / \mathrm{mg}$ protein (range, $0.1-4 \mu \mathrm{g} / \mathrm{mg}$ protein) respectively in patients with SCC. Moreover, stratification analyses of HPV infection did not change the overall relationship between the tumor markers and the pathological subtypes of CC. However, in analyzing each subtype separately, MMP-2 values were significantly higher in patients with HPV infection than in those without it $(P<0.001)$. In patients with $\mathrm{AC}$ the median MMP-2 value was $17.8 \mathrm{ng} / \mathrm{mg}$ protein (range, 14.3-37.9 ng/mg protein) in HPV-infected patients compared with $10.8 \mathrm{ng} / \mathrm{mg}$ protein (range, 7.3$11.2 \mathrm{ng} / \mathrm{mg}$ protein) in non-infected patients, while in patients with SCC, the median MMP-2 value was $15.8 \mathrm{ng} / \mathrm{mg}$ protein (range, 6.6-39.5 ng/mg) in HPVinfected patients and $7.2 \mathrm{ng} / \mathrm{mg}$ protein (range, 5.5$20.9 \mathrm{ng} / \mathrm{mg}$ protein) in non-infected patients. We observed no association between HPV infection and SCCA or TPS in patients with either pathological subtype. 
Table 3

Association between MMP-2 and tumor characteristics

\begin{tabular}{|c|c|c|c|c|}
\hline \multirow[b]{2}{*}{ Model number ${ }^{\mathrm{a}}$} & \multirow[b]{2}{*}{ Tumor characteristic } & \multicolumn{2}{|c|}{$\begin{array}{c}\text { MMP-2 } \\
\text { No. of patients }(\%)\end{array}$} & \multirow[b]{2}{*}{ OR $(95 \% \mathrm{CI})$} \\
\hline & & $<$ Cutoff point & $\geqslant$ Cutoff point & \\
\hline \multirow[t]{3}{*}{ Model 1} & Histological grade ${ }^{\mathrm{b}}$ & & & \\
\hline & I/II & $26(76)$ & $8(24)$ & 1 \\
\hline & III & $5(31)$ & $1(69)$ & $10.2(1.7-60.5)$ \\
\hline \multirow[t]{3}{*}{ Model 2} & Tumor stage $^{\mathrm{c}}$ & & & \\
\hline & $\mathrm{I} / \mathrm{II}$ & $16(67)$ & $8(33)$ & 1 \\
\hline & III/IV & $5(19)$ & $22(81)$ & $13.9(1.4-133.9)$ \\
\hline \multirow[t]{3}{*}{ Model 3} & Tumor recurrence $^{\mathrm{d}}$ & & & \\
\hline & No & $26(84)$ & $5(16)$ & 1 \\
\hline & Yes & $5(26)$ & $14(74)$ & $8.1(1.3-49.1)$ \\
\hline
\end{tabular}

a Models 1 and 2 included age and HPV infection as covariates; Model 3 included age, HPV infection, tumor stage, and tumor histological grade as covariates.

${ }^{\mathrm{b}, \mathrm{d}}$ Estimated cutoff point, $16.9 \mathrm{ng} / \mathrm{mg}$ protein.

${ }^{\mathrm{c}}$ Estimated cutoff point, $13.3 \mathrm{ng} / \mathrm{mg}$ protein.

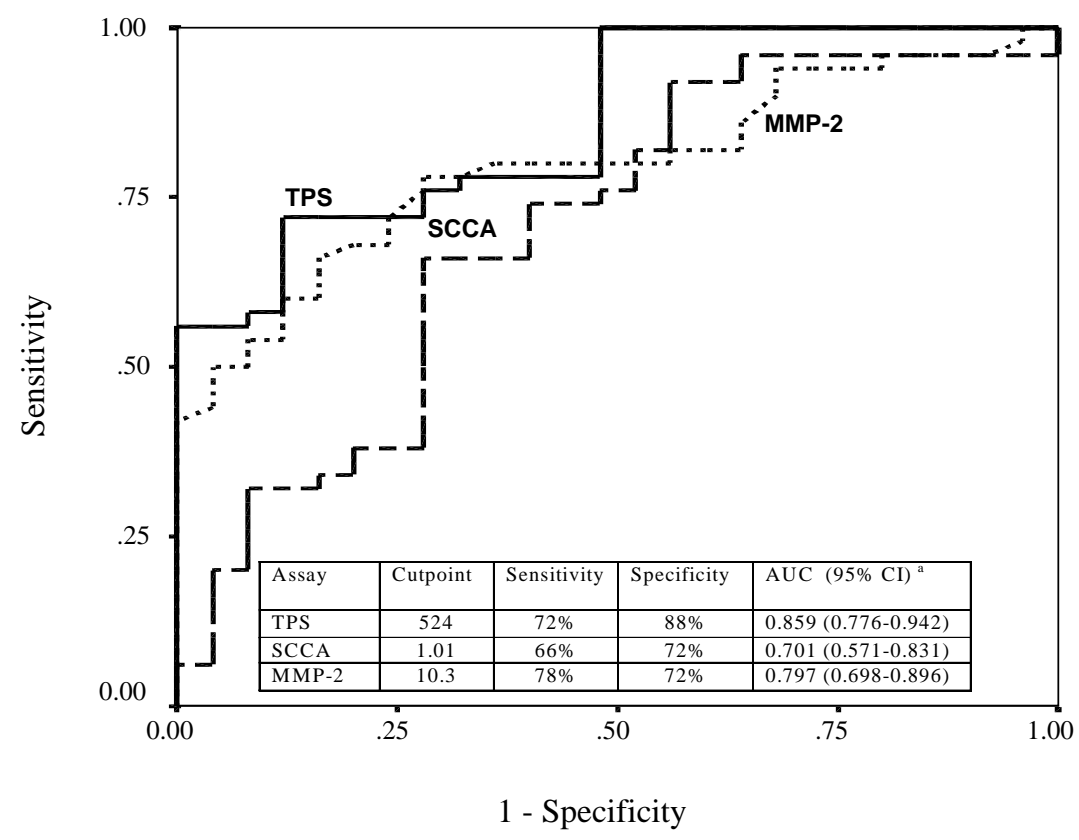

Fig. 1. ROC curves for MMP-2, SCCA, and TPS (patients with CC versus controls).

\subsection{Correlation of study markers with tumor relapse}

Advanced IFGO stage (III and IV) was a significant predictor of cancer recurrence, as the estimated ageadjusted OR was 4.1 (95\% CI, 1.2-18.9). However, histological grade III and HPV infection were not significantly related to tumor recurrence: the estimated OR was 1.5 (95\% CI, 0.3-6.3) and 3.8 (95\% CI, 0.817.9) respectively. In addition to the patients' age, we took into consideration adjustment for tumor stage, histological grade, and HPV infection in determining the impact of the study markers on tumor relapse (multivariate analyses).
A total of 19 patients ( 6 with AC, 13 with SCC) experienced recurrence of the cancer. Local recurrence was found in 7 patients ( 3 with AC, 4 with SCC), whereas distant metastasis was detected in 12 patients (3 with AC, 9 with SCC). All patients with local recurrence had IFGO stage III disease, whereas patients with distant recurrence had an initial diagnosis of IFGO stage IV ( $n=8[67 \%])$ or III disease ( $n=4[33 \%])$. Infection with HPV was significantly more common in patients with a recurrence cancer ( $n=16$ [84\%]) than in patients who did not have a recurrence $(n=18$ [58\%]) $(P=0.05)$. All patients with distant recurrence and 
A

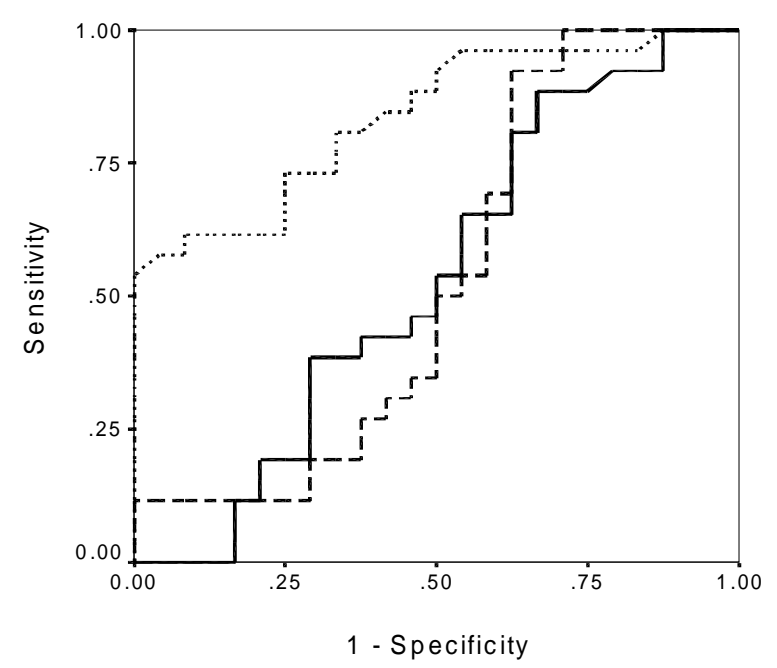

B

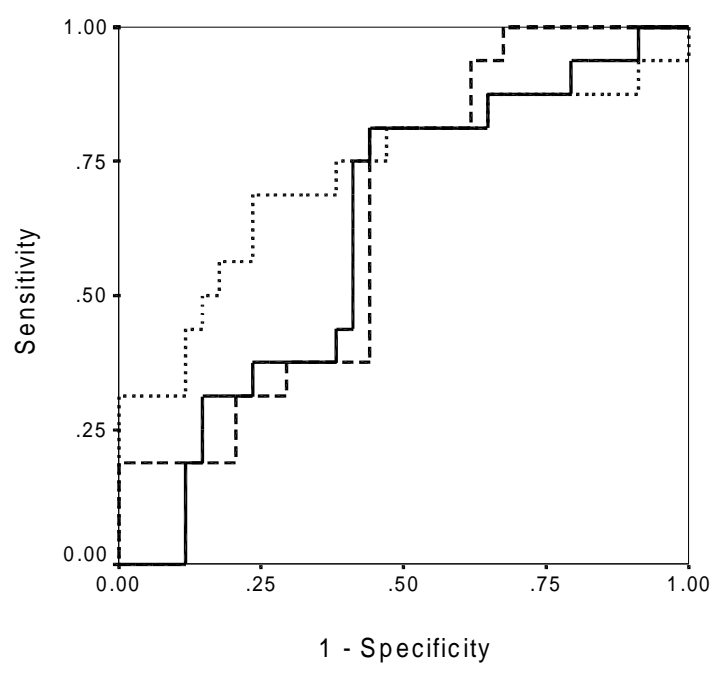

C

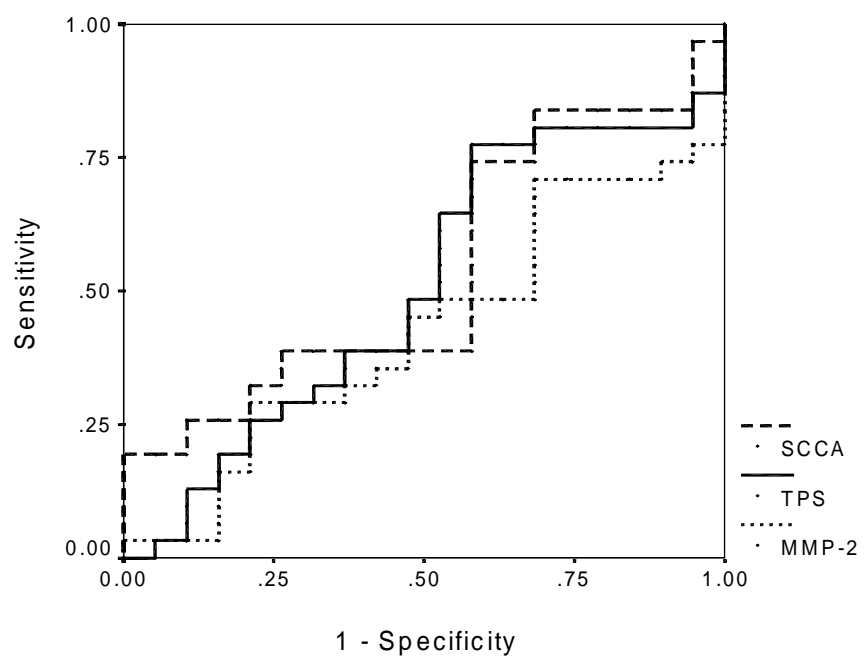

Fig. 2. (A) ROC curves for MMP-2, SCCA, and TPS (early- versus late-stage CC). MMP-2 was the only discriminating marker (cutoff point, $13.3 \mathrm{ng} / \mathrm{mg}$ protein; AUC, 0.837) (B) ROC curves for MMP-2, SCCA, and TPS (poorly differentiated versus well-differentiated histological grade). MMP-2 was the only discriminating marker (best cutoff point, $16.9 \mathrm{ng} / \mathrm{mg}$ protein; AUC, 0.72) (C) ROC curves for MMP-2, SCCA, and TPS (SCC versus AC). MMP-2 was the only discriminating marker (cutoff point, $16.9 \mathrm{ng} / \mathrm{mg}$ protein; AUC, 0.776).

four with local recurrence had previous infection with HPV.

As shown in Fig. 3, the study markers were correlated with tumor recurrence. Only MMP-2 was a significant predictor for tumor recurrences, however. The estimated AUC for MMP-2 was 0.776 (95\% CI, 0.6300.922 ), and the cutoff point was $16.9 \mathrm{ng} / \mathrm{mg}$ protein. There was a significantly higher level of MMP-2 in patients with distant recurrence (median, $24.4 \mathrm{ng} / \mathrm{mg}$ protein [range $15.4-39.5 \mathrm{ng} / \mathrm{mg}$ protein]) than in pa- tients with local recurrence (median, $11.6 \mathrm{ng} / \mathrm{mg}$ protein [range, $5.9-17.8 \mathrm{ng} / \mathrm{mg}$ protein]) $(P<0.001)$. Moreover, this significant difference in MMP-2 level was observed separately in patients with AC and SCC.

Considering HPV infection in patients with local recurrence, the median MMP-2 level in HPV + patients $(n=4)$ was $17.2 \mathrm{ng} / \mathrm{mg}$ protein (range, $7.5-17.8 \mathrm{ng} / \mathrm{mg}$ protein) and in HPV- patients $(n=3)$ was $11 \mathrm{ng} / \mathrm{mg}$ protein (range, $5.9-11.6 \mathrm{ng} / \mathrm{mg}$ protein).

Because advanced disease was significantly related 


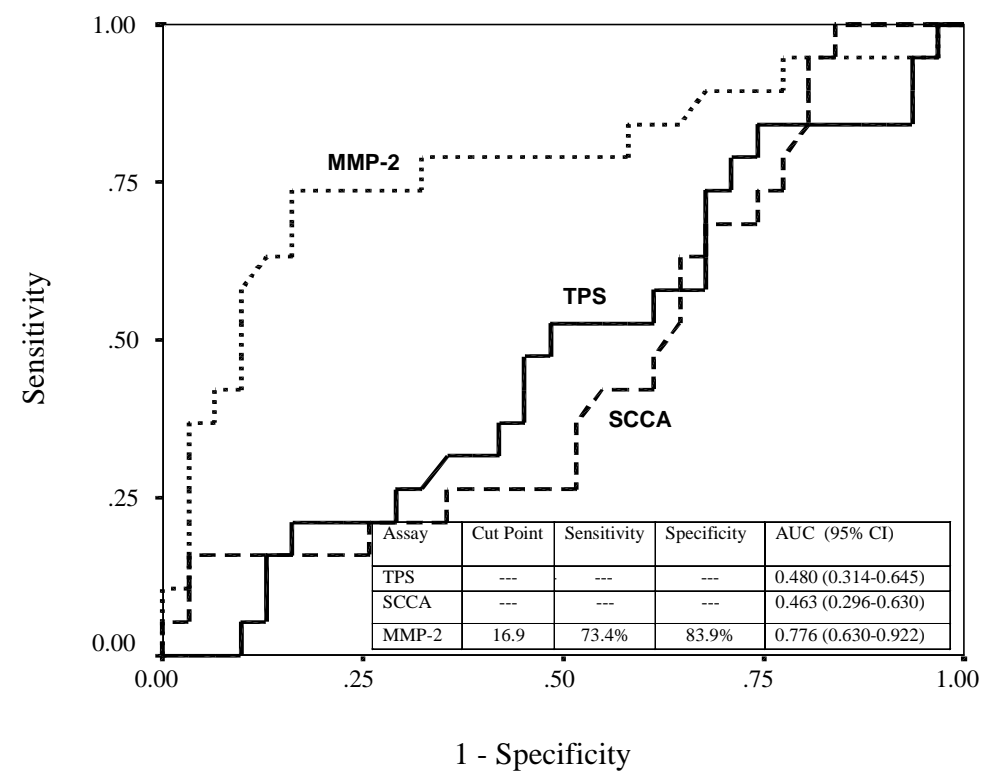

Fig. 3. ROC curves for MMP-2, SCCA, and TPS (relapsed versus nonrelapsed cases).

$\begin{array}{llllllll}1 & 2 & 3 & 4 & 5 & 6 & 7 & 8\end{array}$

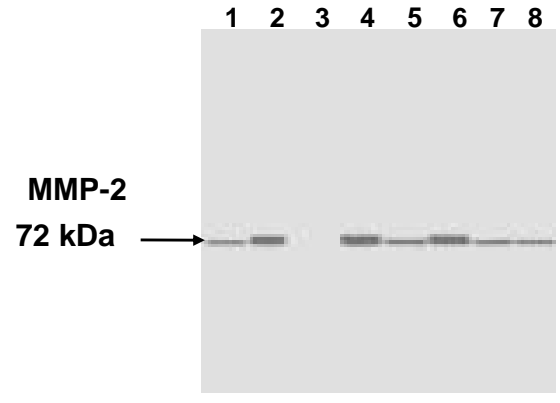

Fig. 4. Western blot analysis of protein expression of MMP-2 (72 $\mathrm{kDa}$ ) in normal cervical tissue (lane 3 ) and early- (lanes 5 and 7) and advanced-stage CC (lanes 2, 4, 6, and 8). Pro-MMP-2 served as a positive control (lane 1).

to relapse, MMP-2 levels were stratified according to IFGO stage (Table 4). The highest median MMP-2 level was found in patients with stage IV carcinoma that had extended beyond the true pelvis and spread to adjacent or distant organs $(P=0.04)$. To further measure the magnitude of the association between MMP-2 and tumor recurrences, patients were categorized into two groups: low risk (MMP-2 $<16.9 \mathrm{ng} / \mathrm{mg}$ protein) and high risk (MMP-2 $\geqslant 16.9 \mathrm{ng} / \mathrm{mg}$ protein). Using logistic regression Model 3 (Table 3), the estimated multivariate OR for tumor recurrence was 8.1 (95\% CI, 1.3-49.1); the OR was adjusted for the patients' age, HPV infection, advanced IFGO stage and histological grade.

\section{Discussion}

$\mathrm{CC}$ is common worldwide [29]. The estimated annual number of new CC cases is 500,000, 79\% of which occur in developing countries, where $\mathrm{CC}$ is consistently the most common cancer, and more than 233,000 deaths occur due to it [30]. In Egypt, CC is the most common female genital tract malignancy [31]. Although 56\% of CC cases are attributable to HPV, other etiological factors related to CC development in Egypt have not been well determined.

The presence and cellular sources of MMP-2 in malignant tumors of different origin were studied previously, producing equivocal results [32-34]. Moreover, production of MMP-2 primarily appears to be a characteristic of invasive tumor cells [7,35]. Therefore, we studied MMP-2 protein expression in a series of malignant and normal cervical tissues with the use of a quantitative EIA method and confirmed the results with Western blotting. We found that the MMP-2 levels was higher in CC tissues $(\geqslant 10.3 \mathrm{ng} / \mathrm{mg}$ protein in $78 \%$ of the cases) than in normal tissues. To the best of our knowledge, very few studies have detected MMP2 expression with the use of EIA, even though it is an ideal quantitative immunological detection method with good quality control, particularly regarding reproducibility and identical probing of many tissue samples at the same time. In previous reports, however, MMP-2 was found to be overexpressed in CC tissues using immunohistochemical methods [36-39]. Thus, it 
Table 4

MMP-2 values in patients with $\mathrm{CC}$ with respect to tumor recurrence and clinical stage

\begin{tabular}{lcccccc}
\hline Recurrence & Stage I & Stage II & Stage III & Stage IV & Total & P value \\
\hline No recurrence & & & & & & 0.08 \\
Number & 11 & 9 & 7 & 4 & 31 & \\
Median & 11.3 & 7.3 & 15.5 & 15.7 & 12.3 & \\
Range & $6.9-17.5$ & $5.5-15.8$ & $6.9-23.1$ & $12.3-37.3$ & $5.5-7.3$ & \\
Recurrence & & & & & & \\
Number & 1 & 3 & 7 & 8 & 19 & 0.04 \\
Median & 7.5 & 17.1 & 18.5 & 24.4 & 18.9 & \\
Range & - & $5.9-17.8$ & $11.0-26.0$ & $15.5-39.5$ & $5.9-39.5$ & \\
\hline
\end{tabular}

is possible that MMP-2 is linked with malignant transformation in the cervix.

Although the regulatory mechanism of tumor invasion is not fully understood, Ueda et al. [40] reported that epidermal growth factor and transforming growth factor- $\alpha$ stimulated functional activity and/or expression of MMP-2 in CC and ovarian carcinoma and promoted the invasive activity of the tumor cells in vitro. On the other hand, calmodulin has been shown to activate pro-MMP-2 in human uterine cervical fibroblasts [41]. Also, recent studies showed that MMP-2 binds to $\alpha(\mathrm{v})$ and $\beta 3$ integrin receptors on the surface of tumor cells and facilitates tumor cell invasion; these receptors are overexpressed in CC cells [42]. Our results showed that MMP-2 overexpression was correlated with advanced-stage carcinoma, raising the possibility of an active role for MMP-2 in CC progression. These results are in accordance with those of other reports $[37,40,43,44]$. Also, overexpression of MMP-2 $(\geqslant 16.9 \mathrm{ng} / \mathrm{mg}$ protein) was a strong independent predictor of early recurrence in the multivariate analysis in our series. Some previous studies showed the same correlation [35,37], while others failed to detect any relationship at all [38].

Early detection of recurrent disease remains a major challenge. However, tumor markers such as SCCA and TPS have been shown to be powerful tools in establishing diagnoses, monitoring patients during therapy, and detecting recurrent CC $[16,18,45-48]$. To evaluate the prognostic role of tissue markers, we analyzed SCCA and TPS in CC tissue specimens. We found that the measured parameters were significantly higher in the patients with CC than in the normal controls. Previous reports demonstrated an elevated SCCA level in sera and cytosol of patients with primary cervical SCC when compared with that in controls. In addition, the antigen levels in previous studies were correlated with the tumor stage (IFGO), lymph node involvement of primary disease, tumor activity, and disease recurrence after therapy in patients with SCC. The authors of the respective reports recommended routine determination of the SCCA level during follow-up of CC [16,18,4547]. Our data showed no relationsh between SCCA and TPS and the clinicopathological findings of the tumors. This may have been due to the small sample size. Even so this is the first study to assess the independent effect of these markers simultaneously in Egyptian women with CC and well document clinicopathological features of the tumor after adjustment for CC risk factors. Except for advanced IFGO stage (III and IV), we found no correlation between HPV infection and grade or pathological type of CC [49].

Taken together, our evaluations of MMP-2, SCCA, and TPS may be of great valuein confirming the diagnosis of CC. Yet MMP-2 is the only marker that is strongly correlated independently with $\mathrm{CC}$ prognosis in this population. This is the first study to quantify MMP-2 in CC tissue specimens obtained from Egyptian women and correlate their value with possible risk and prognostic factors for CC. Special attention should be paid to patients who have a high level of MMP-2 during the follow-up period. Moreover, adjuvant therapy may be necessary for these patients. Further characterization of the expression and use of MMPs and their inhibitors in the progression of solid human neoplasms should lead to the development of novel cancer therapies.

\section{References}

[1] K.N. Gaarenstroom, G.G. Kenter, J.M. Bonfrer and C.M. Korse, Can initial Cyfra 21-1, SCC antigen, and TPA levels in squamous cell cervical cancer predict lymph node metastases or prognosis?, Gynecol. Oncol 77 (2000), 164-170.

[2] L.A. Liotta, C.N. Rao and S.H. Barsky, Tumor invasion and the extracellular matrix, Lab. Invest 49 (1983), 636-649.

[3] H.C. Crawford and L.N. Matrisian, Tumor and stromal expression of matrix metalloproteinases and their role in tumor progression, Invasion Metastasis 14 (1994), 234-245.

[4] S. Aznavoorian, A.N. Murphy, W.G. Stevenson and L.A. Liotta, Molecular aspects of tumor cell invasion and metastasis, Cancer 71 (1993), 1368-1383.

[5] L.N. Matrrisian, The matrix-degrading metalloproteinases, Bioassays 14 (1992), 455-643. 
[6] L.A. Liotta and W.G. Stevenson, Tumor invasion and metastasis: an imbalance of positive and negative regulation, Cancer 51 (1991), 505-509.

[7] G. Giannelli, C. Bergamini, F. Marinosci, E. Fransvea, M. Quaranta, L. Lupo, O. Schiraldi and S. Antonaciet, Clinical role of MMP-2/TIMP-2 imbalance in hepatocellular carcinoma, Int. J. Cancer 97 (2002), 425-431.

[8] S. Curran and G.I. Murray, Matrix metalloproteinases: molecular aspects of their roles in tumour invasion and metastasis, Eur. J. Cancer 36(13 Spec No) (2000), 1621-1630.

[9] A.R. Nelson, B. Fingleton, M.L. Rothenberg and L.M. Matrisian, Matrix metalloproteinases: biologic activity and clinical implications, J. Clin. Oncol 18(5) (2000), 1135-1149.

[10] W.G. Stevenson, P.D. Brown, M. Onisto, A.T. Levy and L.A. Liotta, Tissue inhibitor of metalloproteinase-2 (TIMP2) mRNA expression in tumor cell lines and human tumor tissues, J. Biol. Chem 265 (1990), 13933-13938.

[11] G. Murphy and A.J.P. Docherty, The matrix metalloproteinase and their inhibitors, Am. J. Respir. Cell Mol. Biol 7 (1992), $120-125$.

[12] A.Y. Strongin, I. Collier, G. Bannikov, B.L. Mamer, G.A. Grant and G.I. Goldberg, Mechanism of cell surface activation of 72-KDa type IV collagenase. Isolation of the activated form of the membrane metalloproteinase, J. Biol. Chem 270 (1995), 5331-5338.

[13] A. Talvensaari, M. Apaja-Sarkkinen, M. Hoyhtya, A. Westerlund, U. Puistola and T. Turpeenniemi, Matrix metalloproteinase-2 immunoreactive protein appears early in cervical dedifferentiation, Gynecol Oncol 72 (1999), 306-311.

[14] G.J. Nuovo, P.B. Mac Connel, A. Simsir, F. Valea and D.L. French, Correlation of the in situ detection of polymerase chain reaction-amplified metalloproteinase complementary DNAs and their inhibitors with prognosis in cervical carcinoma, Cancer Res 55 (1995), 257-267.

[15] H. Kato and T. Torigoe, Radioimmunoassay for tumor antigen of human cervical squamous cell carcinoma, Cancer $\mathbf{4 0}$ (1977), 1621-1628.

[16] G. Crombach, A. Scharl, M. Vierbuchen, H. Wurz and A. Bolte, Detection of squamous carcinoma antigen in normal squamous epithelia and in squamous cell carcinoma of the uterine cervix, Cancer 63 (1989), 1337-1342

[17] S. Catalteps, E. Gornstein, C. Schick, Y. Kamachi, K. Chatson, J. Fries, G. Silverman and M. Upton, Co-expression of squamous cell carcinoma antigen 1 and 2 in normal adult human tissues and squamous cell carcinoma, J. Histochem Cytochem 48 (2000), 113-122.

[18] G. Crombach, H. Wurz, F. Herrmann, R. Kreienberg, V. Mobus, P. Schmidt-Rhode, G. Sturm, H. Caffier and H. Kaesemann, [The importance of the SCC antigen in the diagnosis and follow-up of cervix carcinoma, A cooperative study of the Gynecologic Tumor Marker Group (GTMG)], Dtsch. Med. Wochenschr 114 (1989), 700-705.

[19] J.M. Bonfrer, E.M. Groeneveld, C.M. Korse, A. van Dalen, L.C. Oomen and D. Ivanyi, Monoclonal antibody M3 used in tissue polypeptide-specific antigen assay for the quantification of tissue polypeptide antigen recognizes keratin 18, Tumour Biol 15 (1994), 210-222.

[20] B. Bjorklund and R. Einarsson, TPS (tissue polypeptide specific antigen) in oncologic practice: a review with reference to 3000 cases of breast cancer, Tumor Diagn. Ther 17 (1996), 67.

[21] G. Banfi, A. Zebri, S. Pastori, D. Parolini, V. Carlo and P. Bonnini, Behavior of tumor markers CA19.9, CA195, CAM43,
CA242, and TPS in the diagnosis and follow-up of pancreatic cancer, Clin. Chem 39 (1993), 420-423.

[22] M. Tarle, S. Grazio, I. Kraljic and K. Kovacic, A more objective staging of advanced prostate cancer routine recognition of malignant endocrine structure: Assessment of serum TPS PSA and NSE values, Prostate 24 (1994), 143-148.

[23] G. Kornek, T. Schenk, M. Raderer, M. Djavarnmand and W. Scheithauer, Tissue polypeptide specific antigen (TPS) in monitoring palliative treatment response of patients with gastrointestinal tumors, Br. J. Cancer 71 (1995), 182-185.

[24] Y.C. Hung, Y.C. Shiau, W.C. Chang, C.H. Kao and C.C. Lin, Early predicting recurrent cervical cancer with combination of tissue polypeptide specific antigen (TPS) and squamous cell carcinoma antigen (SCC), Neoplasma 49 (2002), 415-417.

[25] S. Eissa and L. Seada, Quantitative of bcl-2 protein in bladder cancer tissue by enzyme immunoassay: comparison with Western blot and immunohistochemistry, Clin. Chem 44 (1998), 1423-1429.

[26] M.M. Bradford, A rapid and sensitive method for quantification of microgram quantities of protein utilizing the principle of protein dye binding, Anal. Biochem 62 (1967), 248-251.

[27] R. Henderson, Assessing test accuracy and its clinical consequences: a primer for receiver operating characteristic curve analysis, Ann. Clin. Biochem 30 (1993), 512-539.

[28] A. Kramar, D. Faraggi, A. Fortune and B. Reiser, mROC: a computer program for combining tumour markers in predicting disease states, Computer Methods \& Programs in Biomedicine 66 (2001), 199-207.

[29] D.M. Parkin, F. Bray, J. Ferlay and P. Pisani, Estimating the world cancer burden: Globocan 2000, Int. J. Cancer 94 (2001), 153-106.

[30] E.C. Turkistanli, N. Sogukpinar, B.K. Saydam and G. Aydemir, Cervical cancer prevention and early detection-the role of nurses and midwives, Asian Pac. J. Cancer Prev 4 (2003), $15-21$.

[31] N. Mokhtar, Cancer Pathology Registry [1989-1994]; National Cancer Institute: Bethesda, MD, Egypt, 1995.

[32] C. Pyke, E. Ralfkiaer, K. Tryggvason and K. Dano, Messenger RNA for two type IV collagenases is located in stromal cells in human colon cancer, Am. J. Pathol 142 (1993), 359-365.

[33] M.S. Naylor, G.W.H. Stamp, B. Davies and F.R. Balkwill, Expression and activity of MMPs and their regulators in ovarian cancer, Int. J. Cancer 58 (1994), 50-56.

[34] M. Polette, N. Gilbert, I. Stas, B. Nawrocki, A. Noel, A. Remacle, W.G. Stetler-Stevenson, P. Birembaut and M. Foidart, Gelatinase expression and localization in human breast cancer. An in situ hybridization study and immunohistochemical detection using confocal microscopy, Virchows Arch 424 (1994), 641-645.

[35] G.G. Garzetti, A. Ciavattini, G. Lucarini, G. Goteri, C. Romanini and G. Biagini, The 72-kDa metalloproteinase immunostaining in cervical carcinoma: relationship with lymph nodal involvement, Gynecol. Oncol 60 (1996), 271-276.

[36] B. Davidson, I. Goldberg, P. Liokumovich, J. Kopolovic, W.H. Gotlieb, L. Lerner-Geva, I. Reder and G. Ben-Baruch, Expression of metalloproteinases and their inhibitors in adenocarcinoma of the uterine cervix, Int. J. Gynecol. Pathol 17 (1998), 295-301.

[37] B. Davidson, I. Goldberg, J. Kopolovic, L. Lerner-Geva, W. Gotlieb, G. Ben-Baruch and R. Reich, MMP-2 and TIMP-2 expression correlates with poor prognosis cervical carcinoma: A clinicopathologic study using immunohistochemistry and mRNA in situ hybridization, Gynecol. Oncol 73 (1999), 372382. 
[38] P.L. Moser, D.G. Kieback, L. Hfler, C. Tempfer, W. Neunteufel and G. Girsch, Immunohistochemical detection of matrix metalloproteinases (MMP) 1 and 2, and tissue inhibitor of metalloproteinase 2 (TIMP) in stage IB cervical cancer, Anticancer Res 19 (1999), 4391-4393.

[39] O. Brummer, G. Bohmer, B. Hollwitz, P. Flemming, K.U. Petry and H. Kuhnle, MMP-1 and MMP-2 in the cervix uteri in different steps of malignant transformation-an immunohistochemical study, Gynecol. Oncol 84(2) (2002), 222-72227227.

[40] M. Ueda, H. Fujii, K. Yoshizawa, Y. Terai, K. Kumagai, K. Ueki and M. Ueki, Effect of EGF and TGF-alpha on invasion and proteinase expression of uterine cervical adenocarcinoma OMC-4 cells, Invasion Metastasis 18 (1998-1999), 176-183.

[41] A. Ito, M. Yamada, T. Sato, M. Seiki, H. Nagase and Y. Mori, Calmodulin antagonists increase the expression of membranetype-1 matrix metalloproteinase in human uterine cervical fibroblasts, Eur. J. Biochem 251 (1998), 453-458.

[42] N. Chattopadhyay, A. Mitra, E. Fre and A. Chatterjee, Human cervical tumor cell $(\mathrm{SiHa})$ surface integrin receptor has associated matrix metalloproteinase (MMP-2) activity, $J$ Cancer Res. Clin. Oncol 127 (2001), 653-658.

[43] M. Ueda, Y. Terai, Y. Yamashita, K. Kumagai, K. Ueki, H. Yamaguchi, D. Akise, Y.C. Hung and M. Ueki, Correlation between vascular endothelial growth factor-C expression and invasion phenotype in cervical carcinomas, Int. J. Cancer 98 (2002), 335-343.
[44] C.Y. Zhou, J.F. Yao and X.D. Chen, [Expression of matrix metalloproteinase-2, 9 and their inhibitor-TIMP 1,2 in human squamous cell carcinoma of uterine cervix], Ai Zheng $\mathbf{2 1}$ (2002), 735-739.

[45] P.G. Rose, S. Baker and L. Serum, Squamous cell carcinoma antigen levels in invasive cervical carcinoma: prediction of response and recurrence, Am. J. Obest. Gynecol 168 (1993), 942-946.

[46] I. Zakrzewska, The value of marker antigens TPS, SCC and CEA in diagnosis, evaluation of histologic type and clinical disease progression in patients with cervical carcinoma, Pol. Merkuriusz Lek 10 (2001), 21-23.

[47] A. Sarandakou, I. Phocas, D. Botsis, K. Sikiotis, D. Rizos, D. Kalambokis, E. Trakakis and A. Chryssikopoulos, Tumorassociated antigens CEA, CA125, SCC and TPS in gynaecological cancer, Eur. J. Gynecol. Oncol 19 (1998), 73-77.

[48] J.L. Hecht, E.E. Sheets and K.R. Lee, Atypical glandular cells of undetermined significance in conventional cervical/vaginal smears and thin-layer preparations, Cancer 96 (2002), 1-4.

[49] M.I. Ahmed, E.E. Salahy, S.T. Fayed, N.G. El-Hefnawy and A. Khalifa, Human papillomavirus infection among Egyptian females with cervical carcinoma: relationship to spontaneous apoptosis and TNF-alpha, Clinical Biochemistry 34 (2001), 491-498. 


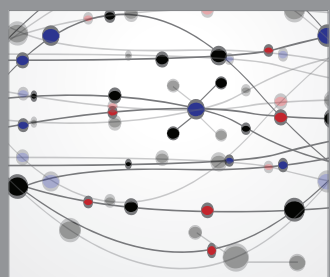

The Scientific World Journal
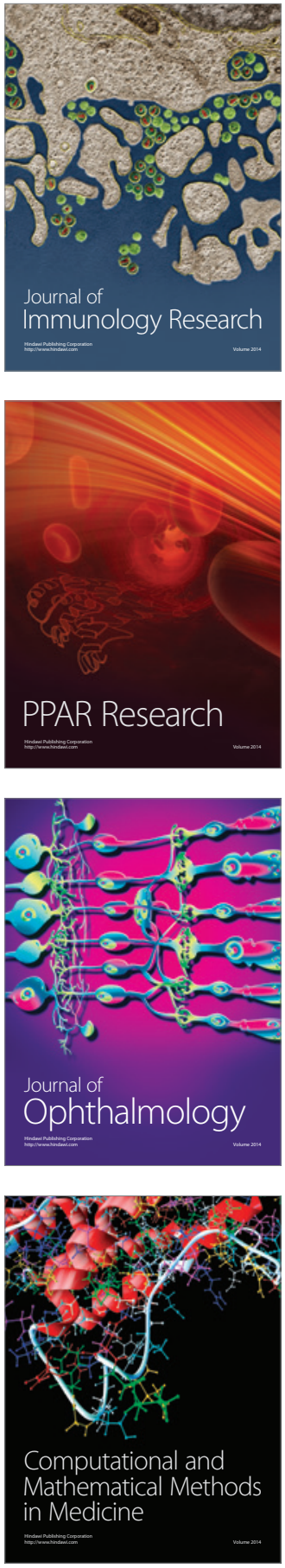

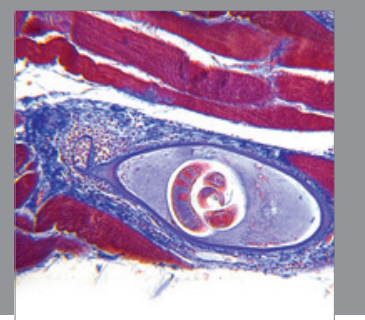

Gastroenterology

Research and Practice
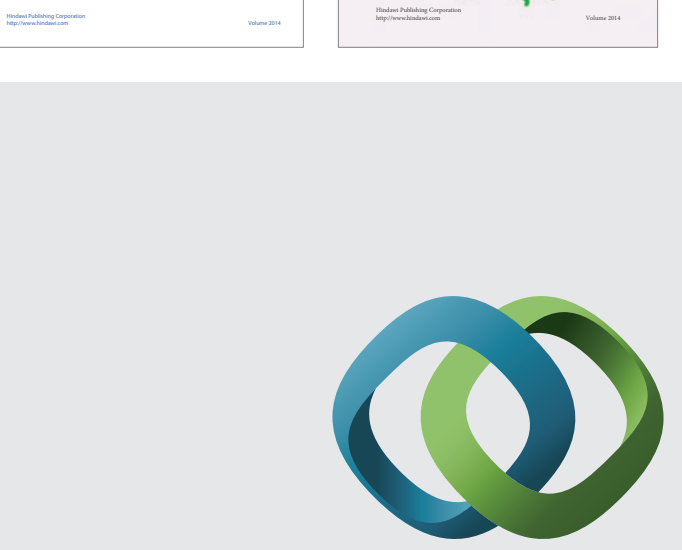

\section{Hindawi}

Submit your manuscripts at

http://www.hindawi.com
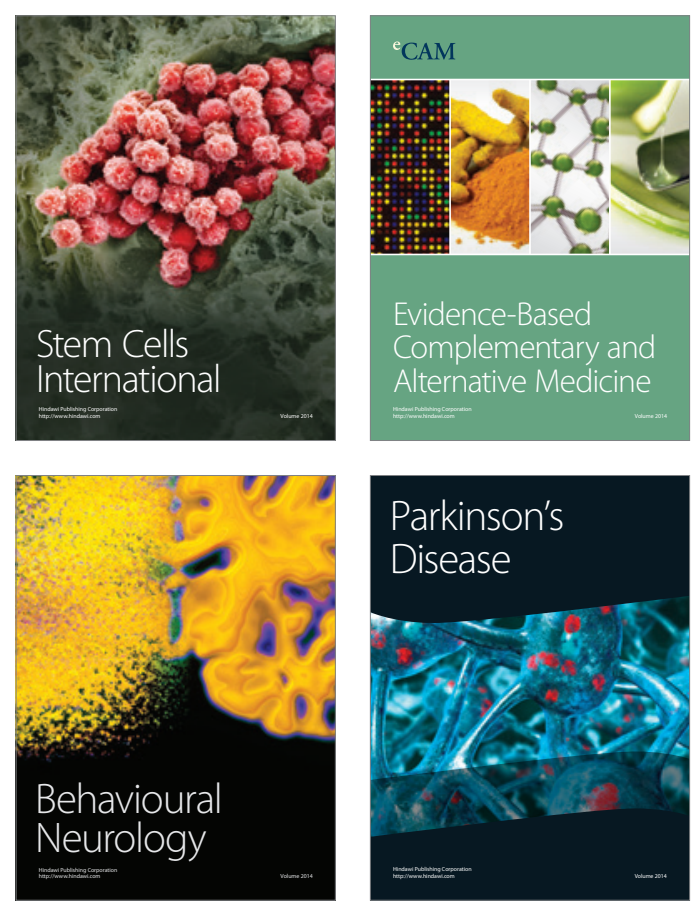

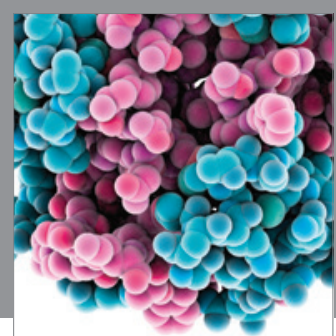

Journal of
Diabetes Research

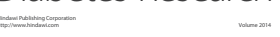

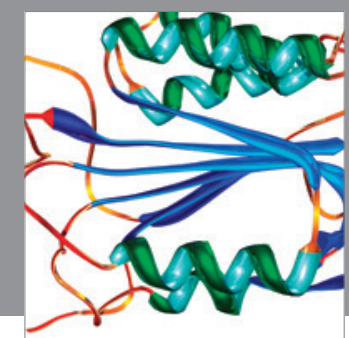

Disease Markers
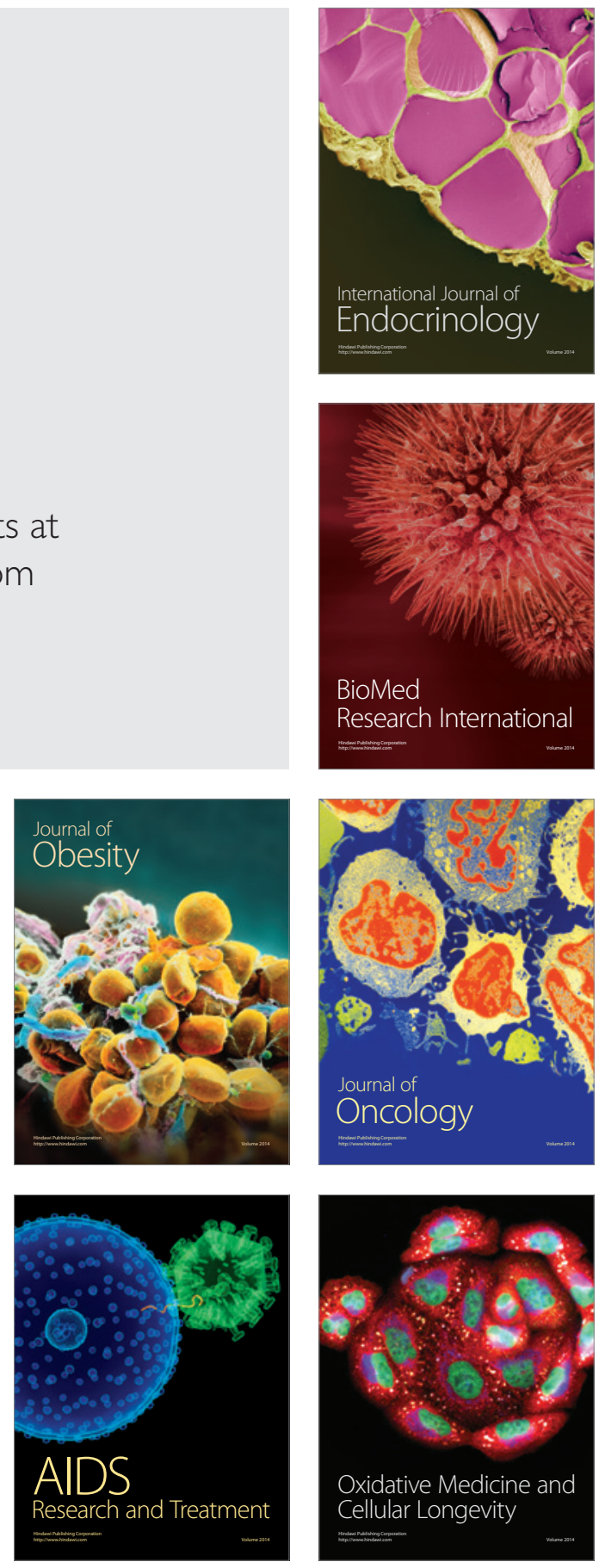